\title{
A Review of Foreign Investments Allowance for Pension Funds in Zimbabwe
}

\author{
Taonaziso Chowa ${ }^{*}$ \\ Richard Mhlangab \\ aLecturer: Department of Insurance and Actuarial Science \\ ${ }^{b}$ Director: Graduate School of Business \\ Faculty of Commerce, National University of Science and Technology (NUST), Zimbabwe \\ *E-mail: teechowa@gmail.com, Cell: +263775 189844
}

\section{Doi:10.5901/mjss.2014.v5n7p171}

\begin{abstract}
The hyperinflation era in Zimbabwe (2003-2008) eroded pensioners' capital values and has seen pre-dollarisation retirees receiving paltry pension payouts from year 2009. We review global trends on foreign investments for pension funds in order to add input to the local debate pitting the Zimbabwe Association of Pension Funds (ZAPF) members against the Insurance and Pensions Commission (IPEC) on whether the Pension and Provident Fund Act [Chapter 24:6] of Zimbabwe should permit foreign/offshore investment. We interview ZAPF members \& partners and carry out secondary analysis of data on pension payouts, asset management and life \& pensions asset allocations and returns post-dollarisation. Findings reveal that meeting liquidity and diversification goals require allowances for foreign investments. ZAPF members and partners would welcome any level of foreign investments allowance, despite Zimbabwe offering weighted returns that are above those currently obtainable from foreign assets. We conclude that there is lack of confidence in the long-term sustainability of the capital values and returns given that the tenure of the prevailing Multi-Currency System (Dollarisation) is uncertain and hence the need to allow limited foreign investment by pension funds.
\end{abstract}

Keywords: Dollarisation, Foreign Investments, Pension Funds, Asset allocation.

\section{Introduction}

\subsection{Pension Funds Investments Regulations in Zimbabwe}

The pension and provident Fund (PPF) Act [Chapter 24:09] (1976 p. 3) describes a fund as any scheme or arrangement the principal object of which is to provide benefits for persons who are or have been members of the scheme arrangement upon retirement on account of age or ill health and may also make provisions for dependents or nominees of deceased members. The vagaries of the years 2003-2008 left Zimbabwean pensioners with nothing to show for their contributions with key culprits being the; hyperinflationary economy, short sighted prescribed asset regulations, rapidly weakening Zimbabwe dollar currency, contagion effects of the 2003/04 banking crisis and premature asset share based conversion methodology of pension fund assets from the Zimbabwean dollar to the United States dollar in February 2009, (Chowa, et al 2013), resulting in some pensioners earning as low as US\$25.00 per month from their retirement plans. The pre-dollarisation retirees under the state's national pension scheme (NPS) administered by NSSA have seen gradual benefit increases from US $\$ 30.00$ in 2009 to US $\$ 60.00$ /month in August 2013 , making it $12 \%$ of the poverty datum line (PDL) level of US $\$ 505.00$, (www.zimstat.co.zw). The NSSA benefits for post dollarisation retirees are however quite high due to the revisions done to the ceiling of insurable earnings from US\$200 to US\$700 in August 2013, (www.nssa.org.zw).

Zimbabwe's PPF Act forbids investments in foreign lands under section 18 stating that: "...a registered fund shall at all times hold its assets in Zimbabwe in investments which are realisable in Zimbabwe..." The IPEC Commissioner rejected proposal for offshore investments citing the slow pace of compliance with the stipulated investment guidelines, low uptake of the few availed prescribed assets by Pension Funds and the huddle in amending both the Insurance and Pensions \& Provident Funds Act, (Mpofu (2010)). The ZSE is considered undervalued and registered very high returns in 2009 (140\%) and 2013 (32.6\%) despite flat returns averaging 2.26\% over the years 2010-2012, (www.zse.co.zw). There is a high concentration of shareholding for ZSE listed counters with the top 20 shareholders accounting for an average of at least $83 \%$ of the total issued share, of which more than $85 \%$ are institutional investors; made up of mainly local life and 
pension funds, (CASE 2011 :p.191, 419-456). Further, Mpofu (2011) laments that; the life assurance industry remains technically oligopolistic with the top three companies led by Old Mutual Zimbabwe controlling $94 \%$ of the over US\$1 billion assets. These life funds are then passed on to be managed by 'related' asset management companies belonging to the parent groups.

\subsection{Purpose of Research}

The research reviews the key issues around foreign investment allowance ceiling and their possible impact on the future pension capital values and Zimbabwean capital markets in light of sister SADC countries and global capital market returns and correlations. We compare IPEC's investment guidelines against actual pension funds and asset manager asset allocations in order to assess their implications to investment decision making views gathered from the interviews with ZAPF members.

\subsection{Organisation of the study}

The rest of this paper is structured as follows: Section 2 reviews the literature on foreign investments by pension funds and global capital markets. Section 3 presents the data and the methodology used to conduct the study. Section 4 discusses the findings and Section 5 concludes the study.

\section{Literature Review}

\subsection{Review of IPEC's investment prescriptions}

Governments across the world try to protect their pensioners through the enactment of regulations that support conservative/low risk investment policies as in passively managed funds, despite the trade-off between risk and return (Srinivas \& Yermo (1999) and Antolin et al. (2009)). Through the use of prescribed assets (PAs) governments also gain access to their economy's pension savings as well as influence investment resources into particular sectors of the economy. Roldos (2004) concludes that restriction on asset allocation and foreign investment are usually meant for macroeconomic stability but highlights the need for close monitoring and proper timing in effecting any changes. However Davis (2002) discourages the enforcement of tighter limits on foreign investments and suggests that it should be left to the market, a practice well adopted in the USA and the UK despite modest PAs levels.

Prescribed assets requirements for Zimbabwe pension funds have been tightened from a pre dollarisation level of $35 \%$ in 2008 to a current ceiling of anything up to 70\%. IPEC's 2013 investment guidelines for life companies and self administered funds proposed the following ceilings in asset allocations; prescribed assets $-70 \%$, property - 40\%, quoted shares $-40 \%$, money markets $-70 \%$, cash $-10 \%$ and not more than $5 \%$ in unquoted shares, (Mpofu, 2013a). These easily fit into the average global asset allocations where by close of $2011,41 \%$ was in equities, $37 \%$ in bonds, $2 \%$ in cash and $20 \%$ in properties and other assets (OECD, 2011). The government of Zimbabwe has intentionally granted PA status to financial instruments aimed at the revival of the capital starved agriculture and manufacturing sectors but these have been shunned by local pension funds. This might be due to the total loss of all cash and PAs investments by pension funds at the turn of dollarisation, which left them with only depressed real estate and equity investments to finance their cash liabilities, (ZAPF, 2011). Renewed interest in the African agriculture sector from similar funds in China and the Middle East, (McNellis, 2009/6) might however push back confidence from local funds.

\subsection{Brief on Pension Funds' foreign investments across the globe}

Zimbabwe's asset allocation guidelines with no foreign investment allowance appears to be lagging behind its SADC peers that have set pension funds ceilings for foreign investments at 25\% for South Africa, 30\% for Zambia and 70\% for Botswana, (Croce 2011). Elsewhere, Brazil and Columbia allow a certain percentage to be invested abroad while Russia disallows state Pension funds and allows only $20 \%$ for private Pension, (Croce, 2011). The World Bank (2008) suggest the need to increase the ability of fund managers to pursue risk adjusted returns as the key driver for foreign investment as this will protect pensioners from increased price volatilities experienced in their economies. ZAPF, (2011) advocates for an initial $5 \%$ with gradual increase to an offshore cap of $15 \%$ with the belief that geographic \& currency diversification through access to international bond markets may cure the negatives from depressed local property market, low to nil dividends from equities and a somewhat weak correlation of returns to global benchmarks. 
Davis (1995) and Bonvin (1997) agree that foreign investment is a means of diversification and therefore meant to either increase returns or reduce volatility, as predicted under the CAPM; assuming an optimal world market portfolio in a fully efficient and integrated capital market. A pension fund may reduce risk while enhancing return by investing in markets which are relatively uncorrelated (or even negatively correlated) with the investor's domestic market contrary to domestic diversification because domestic securities exhibit stronger correlation as a result of their joint exposure to country-specific shocks, (Kurach, 2012). While the construction of an efficient portfolio with an optimal risk-return trade off is a major goal of investment decision making, some investors due to diversification theory believe there should be a mix with foreign investments as a way of hedging (Franzen 2010). Curcuru. et al, (2011) and Kurach (2012) have found an internationally diversified portfolio of bonds to be superior in terms of risk adjusted return relative to an international portfolio of equities. However rising business cycle dependence among the different countries as witnessed during the global financial crisis due mainly to foreign trade deepening and capital accounts liberalization may dilute the benefits.

Reisen (1997) noted that low wealth levels associated with developing-country pensioners leads to low risk tolerance while older people tend to be more risk averse. Theory suggest the use of "Swap Innovation" as a way to satisfy the "foreign asset preference" resulting from the lack of suitable domestic investment assets and the illiquidity in domestic securities markets without the flow of capital to foreign assets. Bodie and Merton (2002) propose an arrangement similar to conventional currency swaps whereby; based on a principal amount, a small-country pension fund with domestic equity holding (in US dollars) could swap the local stock market return per dollar for the total return per dollar on a market-value weighted-average of the world stock markets with a global pension intermediary (GPI).

\subsection{Pension fund investments costs and constraints}

Stewart \& Yermo (2008), Oxera (2007) and Davis (2002) agree that trustee related costs and other factors such as governance through the agency problem, fund size and domestic market liquidity, have had a profound bearing on pension funds performance. These factors have been catalysed by limited jurisdiction of the regulator in some countries and the influence from large Pension Funds. UNCTAD (2011/5) and similar bulletins reveals the fluid nature of investment policy regulations across the globe and points to the higher analytic demands of foreign investment compared to local investing. Mercers (2012) reveal "evidence of a domestic bias, albeit with increasing non-domestic allocations across the EU. Literature suggests that home bias generally observed in pension fund investment should translate into sufficient potential demand for domestic financial assets so as to deepen markets and develop the institutional infrastructure.

Potential explanations of home bias vs cross-border investing have been presented as; taxes and transaction costs, allocation limits, information costs and asymmetries, conservative mandates, different currencies/accounting standards, the physical/economic distance between two countries, language or religious differences and returns benchmarking based on local market, (Davis (2002), Tapia (2008), Sinha and Fiestas (2011) and ASX \& Rusell Investments (2011)). Poor legal protection of minority shareholders and even the governance on a country level also make foreign investment less attractive. Over the years 2008 - 2013 Zimbabwe witnessed policy inconsistencies and political uncertainty from the inclusive governing partners, leading to low inflows of foreign direct investment, (www.africaneconomicoutlook.com).

\section{Methodology}

\subsection{Sampling and data}

This study took a survey targeting ZAPF members and partners through interviews with asset managers, pension fund administrators \& trustees and actuarial consultants in Harare and Bulawayo metropolitans of Zimbabwe. We also carried out a spreadsheet analysis of the collected primary data as well as secondary data on pension payouts, ZSE equity returns \& dividends, market capitalisation and ownership, IPEC reports and Asset Management performance surveys and published results.

We assume an asset share based formula for the computation of the USD cash payout given to pensioners at any future date where:

Asset share $=$ (Individual accumulated credit $/$ Total accumulated credit $) * 100$

USD Payout Value $=$ Asset share * (USD assets less reserve)

NB. Accumulated credit is an accumulation of past contributions using fund interest earned by the fund. 


\subsection{Ethics statement}

This research made use of primary data that already has ethical documentation and only did secondary analysis. Any sensitive company experiences are masked beyond specific identification by future researchers and users of this paper.

\section{Findings and Discussion}

Statistics show that seventy percent of the local pensioners are receiving monthly pensions bellow US $\$ 60$, twenty three percent are receiving between US $\$ 61$ and UD $\$ 200$ and only seven percent earn more than US\$200. This indicates that the majority of Zimbabwe's pensioners are living in poverty given the PDL pegged at US\$505 by December 2013 (www.zimstat.org.zw). Thus; fund managers should invest wisely to avoid any pension value reduction and increase the current pension levels. The pension conversion process would have granted favourable individual benefits if foreign investments were permitted before dollarisation as suggested by the World Bank (2008).

Most fund managers advocated for a higher local asset weight in their portfolios with seventy eight percent of respondents saying they would add some foreign assets in their portfolios, while eleven percent exhibit total "foreign asset preference" and would rather hold a wholly foreign portfolio as they view the local investments as too risky. We also observed some "patriotism" or full bias towards the local market among the other eleven percent who view the associated uncertainties and complexities with the foreign markets as too demanding and would rather maintain their local portfolios. Low levels of liquidity on the ZSE, depressed property market and limited scope of PAs have left the funds locked in certain assets for too long, thereby limiting portfolio revisions and overall returns. These responses indicate the presence of favourable market forces (Davis 2002) whereby opening up foreign investments will only externalise modest amounts of capital, which will be made up of mostly new cash from subscribing members and returns from existing assets.

Properties and equities dominate life and pension funds portfolios making up 36\% apiece on the total life and pension assets as shown in Table 1 below. Zimbabwe's total life and pensions' assets are just above US\$3 billion, with major pension funds portfolios highly weighted in the "risky" capital market stocks and the bulk of their funds locked in properties. The high proportion of cash \& other investments indicates some; limited investment options, tight liquidity in the market and the scarcity of prescribed assets (which are normally short-term assets, hence holdings across all funds at an overall $1 \%$ against a ceiling of $70 \%$ ). Table 1 shows some evident violations of the current IPEC asset allocations guideline for capital market (equity), cash \& other investments and properties (shown in bold font). This weakens ZAPF's bargaining power for foreign investments with IPEC, as the latter has stressed on compliance with the laid down upper limits.

Table 1: Summary of assets held by life and pension funds in Zimbabwe

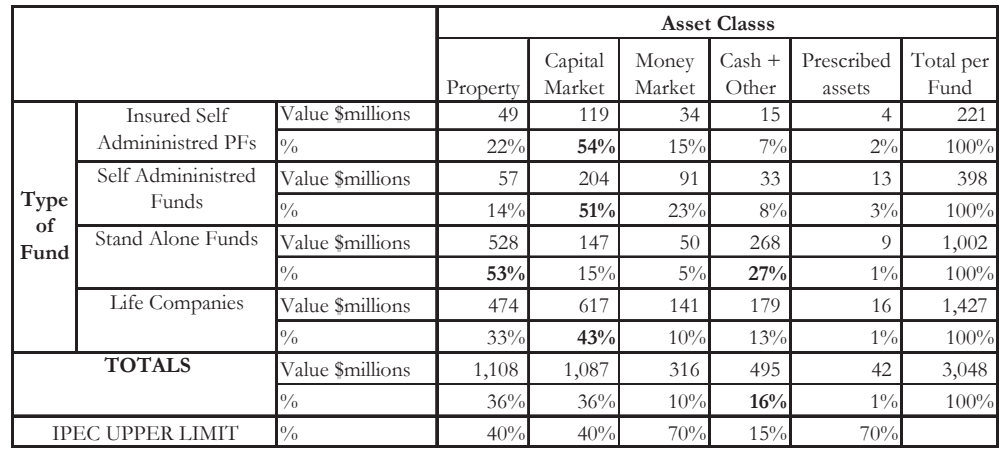

Source: Spreadsheet analysis of Secondary Data (Mpofu (2013b and 2013c))

Asset management companies are usually appointed to manage part or the entire non-property pension funds' assets hence the need to analyse the financials of this special group. The asset allocations for Zimbabwe Asset Managers over the years 2010 - 2013 shows that their investments are predominantly equities (78\%) and money market (20\%) with cash and other alternatives making up the remaining 2\%. The average asset manager returns for 2012 and 2013 were 10.2\% and $21 \%$ respectively, with a whooping average cumulative return since 2009 of $219 \%$ and outperforming the ZSE 
industrial index's 198.5\%. Properties (capital + rental) yielded an average of above $15 \%$ while the local money market is proved very dear given returns of between $9-14 \%$ on the US dollar per annum for the period 2012-2013. Since dollarisation a total of only 13 out of the 62 active listings on the ZSE managed to pay dividends as most companies are still in dire need of capitalisation. For liquidity purposes, this is very unattractive for pension funds that require more of the dividends than capital appreciation (ZAPF, 2011), thereby forcing pension funds to liquidate other assets. We also observe fund manager dominance in the asset management industry, where the top three asset managers control $80 \%$ of the US\$1.1 billion of the total funds under management (FUM) and this point to the larger asset managers dictating the mix of foreign investments for the general market if permitted.

Given that most overseas investments earn an average annual return of less than 10\% (shown in Tapia (2008)), it will be difficult for local fund managers with foreign allocations to beat a wholly localised portfolio. However due to varying economic climate, Zimbabwe has a higher overall risk attributable to some poor performing local investments while the limited asset classes makes it difficult for local fund managers to stabilise the risk and return of assets as shown by negative asset manager weighted average returns of 1.32\% in 2011 and average annual ZSE index underperformance rate of $38 \%$ over the years $2009-2013$. Thus foreign investment allowance may bring flexibility to fund managers and enhance the demand for savings due to the reduction in the perceived loss of savings arising out of any future currency conversion process.

The geographical preferences of local fund managers appear to be limited to their knowledge of the global markets. Fifty percent of the ZAPF members would invest within the SADC region; thirty one percent prefer emerging markets such as Brazil and India, while the remaining nineteen percent would rather invest in tax haven countries such as Dubai and Switzerland. This shows an appetite for higher returns from developing SADC and emerging markets as well as low taxation and transactions cost associated with tax havens. However given that Zimbabwe as an economy in recovery did not feel much of the global financial crisis, foreign investments may expose local funds to the systemic risks of the world markets that are currently depressed. Given the undesirability of shortfall risks to the already depleted capital values, local fund managers should be careful in assuming the perceived diversification benefits.

\section{Concluding Remarks}

We concur with Seidman (1982)'s 30 year old assertion that Zimbabwe need to capture and redirect the domestically generated surpluses to finance a long-term industrial strategy designed to spread productive employment and raise living standards. Given the current low liquidity levels in Zimbabwe, the country needs any surplus cash to be injected into the ailing sectors of the economy as well as increase liquidity for the domestic financial assets, hence the need for controlled foreign investment allowance.

Lessons of the past decade indicate that local assets are exposed to possible changes in the currency regime, limited scope of assets and high implied volatility, making some allowance for foreign investment for hedging purposes most welcome. The current IPEC guidelines gives room for flexibility among fund managers, but should be implemented more on the "new cash" given the current liquidity crunch, so that funds do not have to liquidate existing assets in order to abide by the guidelines. The current standoff is hinged on some parliamentary amendments to the Insurance and Pension \& Provident Funds Act, compliance with scarce/unattractive prescribed assets and revisions to current asset allocations which may require time before pension funds are allowed to invest in foreign assets, unless there is some expedience and flexibility from the regulator (IPEC) and law makers.

The current dispensation of dollarisation gives our pension funds a currency hedge on entry into foreign markets despite the uncertainty in the host nation currency on exit and this could act as a positive catalyst to foreign investment. We conclude that IPEC asset allocations are conservative enough to hedge against downside investment risk and that this could be enhanced through foreign investment to further protect the interests of pensioners and active members as well as raise consumer confidence in committing to savings.

\section{References}

Antolin, P, Blome, S, Karim, D, Payet, S, Peek, J., Scheuenstuhl, G, and Yermo, J, (2009), Investment Regulations And Defined Contribution Pensions, OECD, No. 37

ASX and Rusell Invetments (2011), Long-Term Investing Report, Comparing 10, 20 and 25 Year Performance of Various Investment to December 2010

Bonvin J (1997), Liberalising foreign investments by Pension Funds, OECD.

Bodie, Z. and R.C., Merton, 2002. "International pension swaps", Boston University School of Management Working Paper 02-01. 
CASE (2011), The Central African Stock Exchanges (CASE) Handbook (2011). The New Zanj Publishing House.

Chowa T., Mhlanga R., and Munakamwe M. A. P. (2013): Where Did Our Money Go? Answering The Questions Behind Loss Of Value To Pensioners In Zimbabwe After Multi-Currency Adoption. International Open and Distance Learning Journal, Zimbabwe Open University

Croce R D (2011), Survey of Pension Fund Investment infrastructure-OECD

Curcuru, S E, Thomas, C P, Warnock, F E, Wongswan J, (2011). U.S. International Equity Investment and Past and Prospective Returns

Davis (1995), International Investment of Pension Funds in Europe; scope and Implications for International Financial Stability, Finunzmarkt und Portfolio Management 9 Jahrgang Nr 2

Davis P E (2000/7), Pension Funds, Financial Intermediation and the New Financial Landscape, The Pension Institute, Cass Business School, City University

Davis E P (2002), Pension Fund management and international investment - a global Perspective, The Pensions Institute, Birkbeck College, University Of London

Franzen, D. (2010), Managing Investment Risk in Defined Benefit Pension Funds, OECD No. 38 ,

Kurach R (2012), Pension Funds and Foreign Assets - the Literature Review of the Emerging Market Studies, International Research Journal of Finance and Economics, Issue 97

McNellis P E (2009/6) Foreign Investment In Developing Country Agriculture - The Emerging Role Of Private Sector Finance, FAO No. 28

Mercers (2012). Asset Allocation Survey European Institutional Marketplace Overview

Mpofu M S (2010), IPEC: Market Statistics For Life Assurers For The Year Ended 31 December 2010

Mpofu M S (2011), IPEC: Operations Report For Life Assurers For The Quarter Ended 30 September 2011

Mpofu M S (2013a), Proposed Investment Guidelines For Life Companies And Self Administered Funds, IPEC

Mpofu M S (2013b), IPEC: Half Year Report For Life Assurers, 30 June 2013

Mpofu M S (2013c), IPEC: Half Year Report Self Administered Pension funds 30 June 2013

OECD, (2011/6), Survey of Investment Regulation of Pension Funds

Oxera (2007), Effects of restrictions of cross border investment restrictions on Pension Funds

Pension and Provident Fund (PPF) Act [Chapter 24:09] (1976), Zimbabwe

Reisen H (1997), Liberalising Foreign Investments By Pensions Funds: Positive And Normative Aspects, OECD, No. 120.

Roldos J E (2004). Pension Reform, Investment Restrictions, and Capital Markets, International Monetary Fund PDP/04/4

Seidman A (1982). A Development Strategy For Zimbabwe, Zambezia (1982), X (i).

Sinha S and Fiestas I (2011), Literature Review On The Constraints To Investment In Developing Countries. NATHAN - EME

Srinivas, P.S. and Yermo J (1999) Do Investment Regulations compromise pension fund performance? Evidence from Latin America, Revista de Análisis Económico, Vol. 14, No. 1, pp. 67-120 (June), Santiago.

Stewart F and Yermo J (2008), Pension Fund Governance, Challenges And Potential Solutions OECD No. 18

Tapia, W. (2008), Comparing Aggregate Investment Returns in Privately Managed Pension Funds: An Initial Assessment, OECD No. 21.

UNCTAD, (2011/5). Investment Policy Monitor, UNCTAD Secretariat

World Bank (2008), Country Profiles: Botswana, South Africa \& Zambia

www.africaneconomicoutlook.com, The African Economic Outlook 2012 - Zimbabwe, (AfDB, OECD, UNDP, UNECA),

www.nssa.org.zw: The National Social Security Authority (NSSA) website

www.zse.co.zw: The Zimbabwe Stock Exchange (ZSE) website

www.zimstat.co.zw: Zimbabwe Statistics Agency (ZIMSTAT) Database

ZAPF, (2011), Zimbabwe Association Of Pension Funds; The Case For Offshore Investment For Zimbabwe Pension Funds 